\title{
Tiger beetles (Coleoptera: Cicindelidae) of ancient reservoir ecosystems of Sri Lanka
}

\author{
Chandima Dangalle ${ }^{1}$, Nirmalie Pallewatta ${ }^{2} \&$ Alfried Vogler ${ }^{3}$ \\ 1,2 Department of Zoology, Faculty of Science, University of Colombo, Colombo 03, Sri Lanka \\ ${ }^{3}$ Department of Entomology, The Natural History Museum, London SW7 5BD, United Kingdom \\ Email: ${ }^{1}$ cddangalle@gmail.com (corresponding author) ${ }^{2}$ nirmalip@yahoo.com, ${ }^{3}$ a.vogler@nhm.ac.uk
}

Date of publication (online): 26 April 2012 Date of publication (print): 26 April 2012 ISSN 0974-7907 (online) | 0974-7893 (print)

Editor: Anonimity requested

\section{Manuscript details:}

Ms \# 02896

Received 29 July 2011

Final received 26 December 2011

Finally accepted 19 February 2012

Citation: Dangalle, C., N. Pallewatta \& A. Vogler (2012). Tiger beetles (Coleoptera:Cicindelidae) of ancient reservoir ecosystems of Sri Lanka. Journal of Threatened Taxa 4(4): 2490-2498.

Copyright: (c) Chandima Dangalle, Nirmalie Pallewatta \& Alfried Vogler 2012. Creative Commons Attribution 3.0 Unported License. JoTT allows unrestricted use of this article in any medium for non-profit purposes, reproduction and distribution by providing adequate credit to the authors and the source of publication.

Author Details: See end of this article

Author Contribution: CD conducted field studies in Sri Lanka and laboratory work in the Natural History Museum, London, United Kingdom. She contributed towards research design and methodology and writing of the paper. NP contributed towards formulating the initial concept, research design and methodology and writing of the paper. AV contributed by formulating the initial concept and research design.

Acknowledgments: We wish to thank the National Science Foundation of Sri Lanka (Research Grant No. RG/2003/ZOO/01) for funding the present study. We are also greatly indebted to the Department of Zoology, University of Colombo; the Natural History Museum of London, United Kingdom and the Department of Wildlife Conservation of Sri Lanka. We are grateful to Prof. Nimal Dangalle, Department of Geography, University of Kelaniya, Sri Lanka for his assistance in the preparation of maps and locational lists.

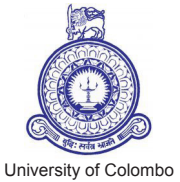

Abstract: The reservoir ecosystems of Sri Lanka are ancient man-made riparian habitats. Adequate food supply and suitable climatic and soil parameters make these habitats ideal for tiger beetles. Twenty-six reservoirs were investigated for the presence of tiger beetles, and four species were recorded: Calomera angulata (Fabricius, 1798), Myriochila (Monelica) fastidiosa (Dejean, 1825), Cylindera (Oligoma) lacunosa (Putzeys, 1875 ) and Lophyra (Lophyra) catena (Fabricius, 1775). Calomera angulata is the most common species, occurring in the majority of reservoir habitats. Key environmental factors of climate and soil were examined and linked to habitat preferences of tiger beetle species.

Keywords: Coleoptera, Cicindelidae, habitat preferences, reservoirs, tiger beetles.

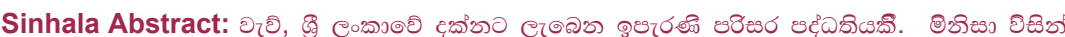

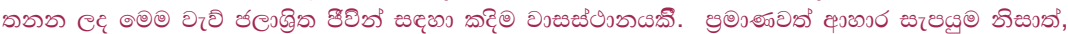

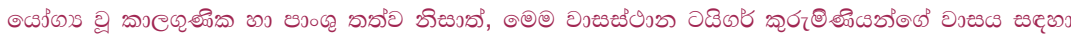

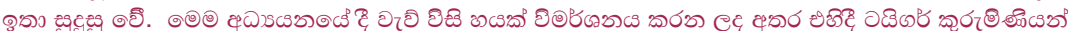

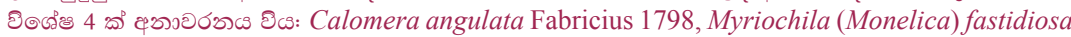
Dejean 1825, Cylindera (Oligoma) lacunosa Putzeys 1875, Lophyra (Lophyra) catena Fabricius

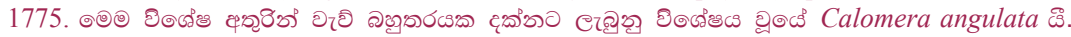

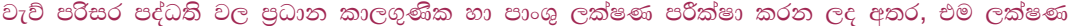

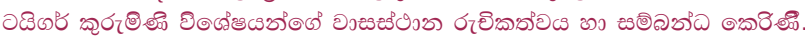

\section{INTRODUCTION}

Tiger beetles (Coleoptera: Cicindelidae) have been recorded from Sri Lanka since the 1860s. Identified species, their distributions and habitats are given by Tennent (1860), Horn (1904), Fowler (1912), Wiesner (1975), Naviaux (1984) and Acciavatti \& Pearson (1989). These records together show 59 tiger beetle species from Sri Lanka, of which 39 are endemic.

The majority of tiger beetles in Sri Lanka are terrestrial and diurnal, and are included in the genera Cicindela, Calochroa, Calomera, Lophyra, Jansenia, Cylindera, Myriochila, Hypaetha and Callytron. These species occupy a variety of habitats on the island such as riverine sandy areas, beaches and coastal areas, lagoons by the ocean, forests, forest openings, wet rocks along water courses, grasslands, fallow fields and road cuts (Wiesner 1975; Naviaux 1984; Acciavatti \& Pearson 1989). However, the habitats of many species are unrecorded, and current localities of occurrence are unknown.

Tiger beetles are highly habitat-specific (Knisley \& Hill 1992; Adis et al. 1998; Morgan et al. 2000; Cardoso \& Vogler 2005; Satoh et al. 2006; Pearson \& Cassola 2007). Human activities in Sri Lanka have caused habitat loss, fragmentation and degradation, increasing the risk of extinction for many species including endemics (IUCN 2006). Therefore, 
it is highly likely that insect species with narrow habitat requirements, such as the tiger beetles, will be threatened with extinction in the near future given the pressures of development in the country. Therefore, it is imperative that the current occurrence and status of tiger beetles be investigated.

The ancient man-made reservoir (tank) systems are a unique habitat in Sri Lanka, dating back to about 2500 years when the country had a hydraulic civilization. They were built by the kings for irrigation purposes, domestic and municipality needs, and flourish today in the ancient kingdoms of Anuradhapura, Polonnaruwa and Sigiriya in the North-Central Province of the country (Bandaragoda 2006). Over 30,000 reservoirs have been built in Sri Lanka, and some are still found covered by thick jungle dotting the landscape all over the country, especially in the dry zone (De Silva 1988). A noteworthy, modern day feature of this unique system for water storage is that it performs important roles in conservation of Sri Lankan biodiversity apart from the original roles for which they were constructed. Although the reservoirs are man-made they very often blend seamlessly with the natural environment and it is nearly impossible to separate the man-made, reservoir-based agricultural environment from the natural environment.

We report here the first recorded occurrence of tiger beetle species from the ancient reservoir ecosystems of Sri Lanka. The study reports the occurrence of four tiger beetle species that have been previously found in other habitat types in Sri Lanka and other countries, associated with reservoir habitats for the first time. Further, we reveal the habitat preferences of the tiger beetle species associated with the reservoir habitats of Sri Lanka.

\section{METHODS AND MATERIALS}

\section{Study area}

Twenty six reservoirs were surveyed for the occurrence of tiger beetle species from December, 2003 to November 2005. Most of the reservoirs were located in the North-Central Province of the country, while the other reservoirs were located in the NorthWestern, Southern, Central and Western provinces of the island (Fig. 1, Table 1).

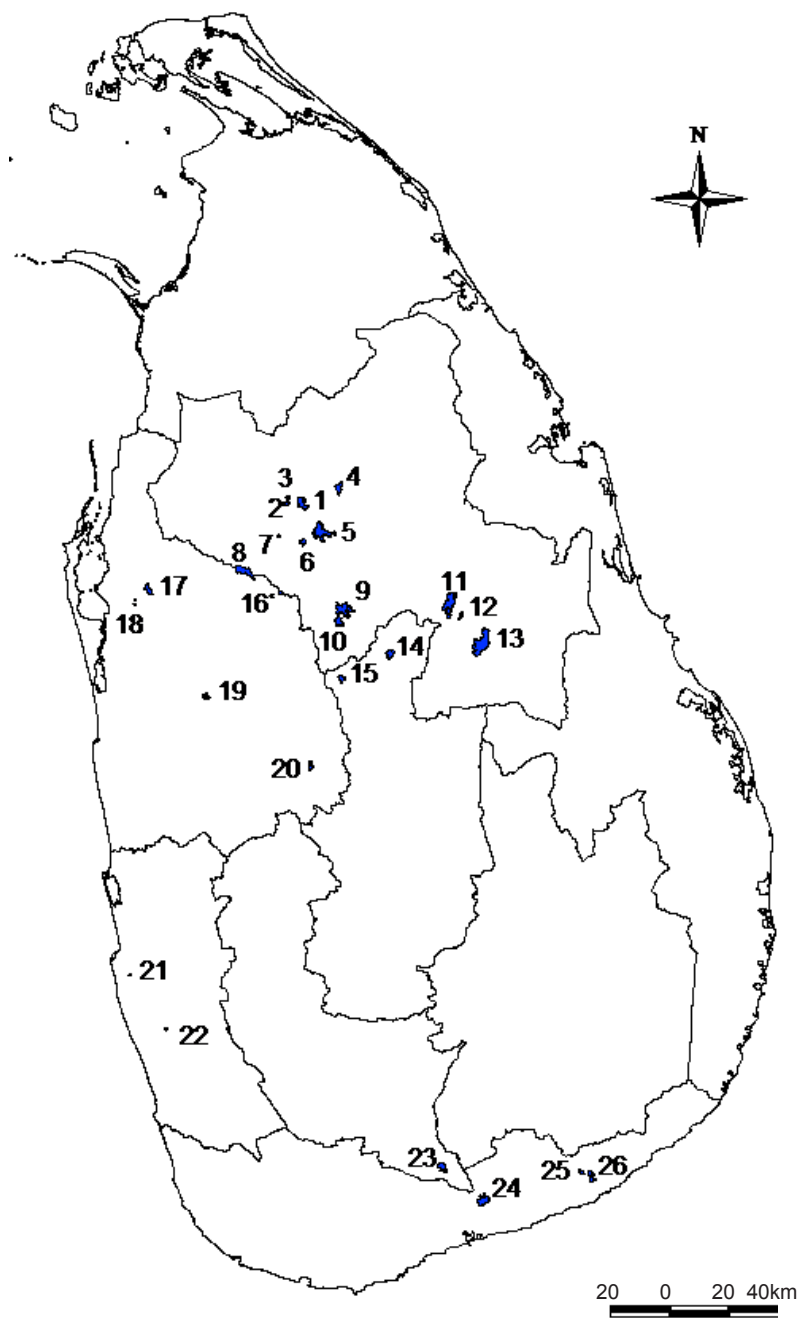

Figure 1. Reservoirs of Sri Lanka surveyed for the occurrence of tiger beetles

\section{Measuring habitat variables of the reservoirs}

The habitat variables of the climate and soil of the reservoirs in which tiger beetles occurred were measured as follows:

(i) Climate variables: The ambient temperature, degree of solar radiation, relative humidity and wind speed of the habitat were recorded using a portable integrated weather station with optional sensors (Health EnviroMonitor, Davis Instrument Corp., Hayward, CA, USA).

(ii) Soil variables: These included the soil type/ texture, using the sedimentation technique "soil textural triangle" (Bierman 2007); soil colour, measured by comparison with a Munsell soil colour chart; soil temperature, determined by using an Insert soil thermometer (SG 680-10) ranging from -10 to $110{ }^{\circ} \mathrm{C}$; soil $\mathrm{pH}$, determined by using a portable soil 
Table 1. The reservoirs of Sri Lanka surveyed for tiger beetles

\begin{tabular}{|c|c|c|c|}
\hline & Reservoir & Location & $\begin{array}{l}\text { Date } \\
\text { surveyed }\end{array}$ \\
\hline 1 & Nuwara Wewa & $\begin{array}{l}\text { Anuradhapura District, North- } \\
\text { Central Province } \\
8^{0} 20^{\prime} 88^{\prime \prime} \mathrm{N} \& 80^{\circ} 25^{\prime} 97^{\prime \prime} \mathrm{E} \\
80.69 \mathrm{~m}\end{array}$ & $\begin{array}{l}\text { December } \\
2003, \text { July } \\
2004\end{array}$ \\
\hline 2 & Thisa Wewa & $\begin{array}{l}\text { Anuradhapura District, North- } \\
\text { Central Province } \\
8^{0} 20^{\prime} 53^{\prime \prime} \mathrm{N} \& 80^{\circ} 23^{\prime} 06^{\prime \prime} \mathrm{E} \\
79.86 \mathrm{~m}\end{array}$ & $\begin{array}{l}\text { December } \\
2003\end{array}$ \\
\hline 3 & Abhaya Wewa & 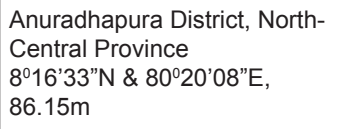 & $\begin{array}{l}\text { December } \\
2003\end{array}$ \\
\hline 4 & $\begin{array}{l}\text { Mahakanadarawa } \\
\text { Wewa }\end{array}$ & $\begin{array}{l}\text { Anuradhapura District, North- } \\
\text { Central Province } \\
8^{0} 23^{\prime} 25^{\prime \prime} \mathrm{N} \& 80^{\circ} 31^{\prime} 98 \text { "E, } \\
85.04 \mathrm{~m}\end{array}$ & July 2004 \\
\hline 5 & $\begin{array}{l}\text { Nachchaduwa } \\
\text { Wewa }\end{array}$ & $\begin{array}{l}\text { Anuradhapura District, North- } \\
\text { Central Province } \\
8^{0} 15^{\prime} 85^{\prime \prime} \mathrm{N} \& 80^{\circ} 28^{\prime} 67^{\prime \prime} \mathrm{E} \\
96.01 \mathrm{~m}\end{array}$ & July 2004 \\
\hline 6 & Turuwila Wewa & 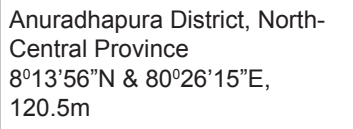 & April 2005 \\
\hline 7 & Talawa Wewa & $\begin{array}{l}\text { Anuradhapura District, North- } \\
\text { Central Province } \\
8^{0} 16^{\prime} 08^{\prime \prime} \mathrm{N} \& 80^{\circ} 20^{\prime} 19^{\prime \prime} \mathrm{E} \\
105.69 \mathrm{~m}\end{array}$ & April 2005 \\
\hline 8 & $\begin{array}{l}\text { Rajangana } \\
\text { reservoir }\end{array}$ & $\begin{array}{l}\text { Tambuttegama, Anuradhapura } \\
\text { District, North-Central Province } \\
\text { 8013'06"N \& 80²5'49"E, } \\
79.75 \mathrm{~m}\end{array}$ & April 2005 \\
\hline 9 & Kala Wewa & $\begin{array}{l}\text { Anuradhapura District, North- } \\
\text { Central Province } \\
8^{\circ} 02^{\prime} 011^{\prime \prime} \mathrm{N} \& 80^{\circ} 32^{\prime} 16^{\prime \prime} \mathrm{E} \\
125.88 \mathrm{~m}\end{array}$ & July 2004 \\
\hline 10 & Balalu Wewa & $\begin{array}{l}\text { Anuradhapura District, North- } \\
\text { Central Province } \\
8^{\circ} 02^{\prime} 011^{\prime \prime} \mathrm{N} \& 80^{\circ} 32^{\prime} 18^{\prime \prime} \mathrm{E} \\
125.64 \mathrm{~m}\end{array}$ & July 2004 \\
\hline 11 & Minneriya Wewa & $\begin{array}{l}\text { Polonnaruwa District, North- } \\
\text { Central Province } \\
8^{0} 02^{\prime} 33^{\prime \prime} \mathrm{N} \& 80^{\circ} 02^{\prime} 36 \text { "E, } \\
96.25 \mathrm{~m}\end{array}$ & $\begin{array}{l}\text { December } \\
2003\end{array}$ \\
\hline 12 & Giritale Wewa & $\begin{array}{l}\text { Polonnaruwa District, North- } \\
\text { Central Province } \\
7^{0} 566^{\prime} 32^{\prime \prime} \mathrm{N} \& 81^{\circ} 01^{\prime} 09^{\prime \prime} \mathrm{E} \\
131.45 \mathrm{~m}\end{array}$ & $\begin{array}{l}\text { December } \\
2003\end{array}$ \\
\hline 13 & $\begin{array}{l}\text { Parakrama } \\
\text { Samudra }\end{array}$ & $\begin{array}{l}\text { Polonnaruwa District, North- } \\
\text { Central Province } \\
\text { 7057'01"N \& 8059'98"E, } \\
56.69 \mathrm{~m}\end{array}$ & $\begin{array}{l}\text { December } \\
2003\end{array}$ \\
\hline
\end{tabular}

\begin{tabular}{|c|c|c|c|}
\hline & Reservoir & Location & $\begin{array}{l}\text { Date } \\
\text { surveyed }\end{array}$ \\
\hline 14 & Kandalama Wewa & $\begin{array}{l}\text { Dambulla, Matale District, } \\
\text { Central Province } \\
\text { 7052'51"N \& 8041'51"E, } \\
\text { 176.52m }\end{array}$ & $\begin{array}{l}\text { December } \\
2003, \\
\text { December } \\
2005\end{array}$ \\
\hline 15 & Devahuwa Wewa & $\begin{array}{l}\text { Dambulla, Matale District, } \\
\text { Central Province } \\
\text { 7048'41"N \& 803'20”E, } \\
181.66 \mathrm{~m}\end{array}$ & $\begin{array}{l}\text { December } \\
2003\end{array}$ \\
\hline 16 & $\begin{array}{l}\text { Kurundankulama } \\
\text { Wewa }\end{array}$ & $\begin{array}{l}\text { Anuradhapura District, North- } \\
\text { Central Province } \\
8^{0} 35^{\prime} 01 \text { "N \& 804'18"E, } \\
105.5 \mathrm{~m}\end{array}$ & April 2005 \\
\hline 17 & Tabbowa Wewa & $\begin{array}{l}\text { KaruwalagasWewa, Puttalam } \\
\text { District, North-Western } \\
\text { Province } \\
8^{\circ} 04^{\prime} 32^{\prime \prime N} \& 79^{\circ} 56^{\prime} 69^{\prime \prime} \mathrm{E} \\
20.42 \mathrm{~m}\end{array}$ & June 2004 \\
\hline 18 & Billu Wewa & $\begin{array}{l}\text { Puttalam District, North- } \\
\text { Western Province } \\
\text { 7008'54"N \& 79051'20"E } \\
20.15 \mathrm{~m}\end{array}$ & June 2004 \\
\hline 19 & Magalla Wewa & $\begin{array}{l}\text { Nikawaratiya, Kurunegala } \\
\text { District, North-Western } \\
\text { Province } \\
7^{0} 44^{\prime} 31^{\prime \prime} \mathrm{N} \& 80^{\circ} 07^{\prime} 47^{\prime \prime} \mathrm{E}, \\
54.62 \mathrm{~m}\end{array}$ & April 2005 \\
\hline 20 & Batalagoda Wewa & $\begin{array}{l}\text { Ibbagamuwa, Kurunegala } \\
\text { District, North-Western } \\
\text { Province } \\
7^{0} 32^{\prime} 12^{\prime \prime N} \& 80^{\circ} 02^{\prime} 04^{\prime \prime} \mathrm{E} \\
131.98 \mathrm{~m}\end{array}$ & $\begin{array}{l}\text { December } \\
2003\end{array}$ \\
\hline 21 & Kimbulwila Wewa & $\begin{array}{l}\text { Malwana, Gampaha District, } \\
\text { Western Province } \\
6^{0} 56^{\prime} 57^{\prime \prime} \mathrm{N} \& 80^{\circ} 00^{\prime} 55^{\prime \prime} \mathrm{E} \\
23.37 \mathrm{~m}\end{array}$ & $\begin{array}{l}\text { August } \\
2003\end{array}$ \\
\hline 22 & $\begin{array}{l}\text { Gammanpila } \\
\text { Wewa }\end{array}$ & $\begin{array}{l}\text { Bandaragama, Kalutara } \\
\text { District, Western Province } \\
6^{0} 31^{\prime} 48^{\prime \prime} \mathrm{N} \& 79^{\circ} 58^{\prime} 08^{\prime \prime} \mathrm{E} \\
5.25 \mathrm{~m}\end{array}$ & June 2004 \\
\hline 23 & Chandrika Wewa & $\begin{array}{l}\text { Embilipitiya, Hambantota } \\
\text { District, Southern Province } \\
\text { 6019'03"N \& 80051'19"E, } \\
\text { 9.76m }\end{array}$ & $\begin{array}{l}\text { November } \\
2004\end{array}$ \\
\hline 24 & $\begin{array}{l}\text { Ridiyagama } \\
\text { Wewa }\end{array}$ & $\begin{array}{l}\text { Ambalantota, Hambantota } \\
\text { District, Southern Province } \\
6^{0} 20^{\prime} 89^{\prime \prime} \mathrm{N} \& 80^{\circ} 98^{\prime} 56^{\prime \prime} \mathrm{E} \\
2.74 \mathrm{~m}\end{array}$ & $\begin{array}{l}\text { November } \\
2004\end{array}$ \\
\hline 25 & Tissa Wewa & $\begin{array}{l}\text { Tissamaharama, Hambantota } \\
\text { District, Southern Province } \\
\text { 6017'12"N \& 81016'91"E, } \\
16.16 \mathrm{~m}\end{array}$ & $\begin{array}{l}\text { November } \\
2005\end{array}$ \\
\hline 26 & Yoda Wewa & $\begin{array}{l}\text { Kirinda, Hambantota District, } \\
\text { Southern Province } \\
\text { 6015'60"N \& 81018'61"E, } \\
13.11 \mathrm{~m}\end{array}$ & $\begin{array}{l}\text { November } \\
2005\end{array}$ \\
\hline
\end{tabular}

pH meter (Westminster, No. 259); soil moisture, determined by selecting five random spots of a locality and collecting samples down to a depth of $10 \mathrm{~cm}$ and estimating the difference in weight before and after oven drying to $107-120{ }^{\circ} \mathrm{C}$ in the laboratory; and soil salinity, determined by a YSI model 30 hand-held salinity meter.

\section{Collection of beetles}

Tiger beetle species were surveyed between 1000 $-1500 \mathrm{hr}$ at all localities. Adult tiger beetles were searched in specific habitats including the bank of the 
reservoir, surrounding shrub area near the reservoir, and off-road trails. Beetles were collected using a standard insect net. Specimens were preserved in $96 \%$ ethanol and stored at $-20^{\circ} \mathrm{C}$ after examining for morphological characters and recording morphometric measurements. Permission to enter various areas for tiger beetle collection and for collecting specimens was obtained from the Department of Wildlife Conservation of Sri Lanka.

\section{Identification of tiger beetles}

Taxonomic keys of the Cicindela of the Indian subcontinent by Acciavatti \& Pearson (1989), descriptions of Horn (1904) and Fowler (1912) were used to identify the species and confirmation of identification was done through comparisons with specimens available at the National Museum of Colombo and Natural History Museum (NHM), London. Taxonomic names of species, with the present nomenclatural changes, are based on Wiesner 1992, except for the use of Calomera instead of Lophyridia, which is based on Lorenz (1998).

The beetles were observed under a photomicrographic attachment which was also used in photographing each specimen (Nikon AFX-DX, Tokyo, Japan).

\section{RESULTS}

Tiger beetle species were recorded from the sandy banks of eleven reservoirs of Sri Lanka. Most of the reservoirs were located in the North-Central and

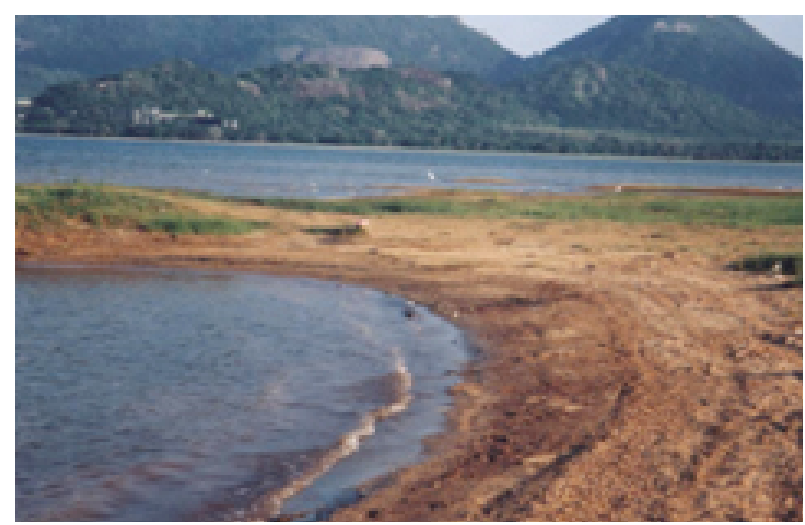

Image 1. Kandalama Reservoir, Matale District, Central Province of Sri Lanka with the sandy bank on which tiger beetles were found
Table 2. Reservoirs ecosystems of Sri Lanka and associated tiger beetles

\begin{tabular}{|l|l|}
\hline Reservoir & Species Recorded \\
\hline Nuwara Wewa & Myriochila (Monelica) fastidiosa \\
\hline Thisa Wewa & Calomera angulata \\
\hline Mahakanadarawa Wewa & Calomera angulata \\
\hline Nachchaduwa Wewa & $\begin{array}{l}\text { Calomera angulata } \\
\text { Myriochila (Monelica) fastidiosa }\end{array}$ \\
\hline Kala Wewa & Calomera angulata \\
\hline Parakrama Samudra & Calomera angulata \\
\hline Kandalama Wewa & $\begin{array}{l}\text { Calomera angulata } \\
\text { Myriochila (Monelica) fastidiosa }\end{array}$ \\
\hline Devahuwa Wewa & $\begin{array}{l}\text { Calomera angulata } \\
\text { Cylindera (Oligoma) lacunosa } \\
\text { Lophyra (Lophyra) catena }\end{array}$ \\
\hline Tabbowa Wewa & $\begin{array}{l}\text { Calomera angulata } \\
\text { Myriochila (Monelica) fastidiosa }\end{array}$ \\
\hline Batalagoda wewa & Calomera angulata \\
\hline Ridiyagama Wewa & Lophyra (Lophyra) catena \\
\hline
\end{tabular}

North-Western provinces while a few were located in the Central and Southern provinces (Image 1, Table 2).

\section{Habitat variables of the reservoirs}

Habitat sampling from December 2003 to November 2005 revealed that tiger beetles occur on sandy soils of reservoirs in areas of sparse vegetation. The beetles exhibited a significant preference for sunlit areas with high solar radiation where climatic and soil temperatures were only slightly different. A soil moisture of $4.25 \pm 0.67 \%$ prevailed in the soils of the reservoirs which were more or less neutral with a salinity of zero value. The climatic and soil conditions of the reservoir habitats are given in Table 3.

\section{Tiger beetle species recorded from the reservoirs of Sri Lanka}

Four species of tiger beetles, Calomera angulata (Fabricius, 1798), Myriochila (Monelica) fastidiosa (Dejean, 1825), Cylindera (Oligoma) lacunosa (Putzeys, 1875) and Lophyra (Lophyra) catena (Fabricius, 1775) were recorded from the reservoir habitats of Sri Lanka (Table 2).

\section{Calomera angulata (Fabricius, 1798) (Image 2)}

Calomera angulata was the most common tiger beetle species in reservoir ecosystems and dominated all other species in terms of occurrence (Fig. 2). 
Table 3. Climate and soil parameters of the reservoir habitats of tiger beetles recorded at the time of collection

\begin{tabular}{|c|c|c|c|c|c|c|c|c|c|c|}
\hline Reservoir & $\begin{array}{c}\text { Tempera- } \\
\text { ture }\left({ }^{\circ} \mathrm{C}\right)\end{array}$ & $\begin{array}{c}\text { Solar } \\
\text { Radiation } \\
\left(\mathrm{w} / \mathrm{m}^{2}\right)\end{array}$ & $\begin{array}{c}\text { Relative } \\
\text { Humidity } \\
(\%)\end{array}$ & $\begin{array}{l}\text { Wind } \\
\text { Speed } \\
(\mathrm{MPH})\end{array}$ & $\begin{array}{l}\text { Soil } \\
\text { Type }\end{array}$ & Soil Colour & $\begin{array}{l}\text { Soil Tempe- } \\
\text { rature }\left({ }^{\circ} \mathrm{C}\right)\end{array}$ & Soil pH & $\begin{array}{c}\text { Soil } \\
\text { Moisture } \\
(\%)\end{array}$ & $\begin{array}{c}\text { Soil } \\
\text { Salinity } \\
\text { (ppt) }\end{array}$ \\
\hline Nuwara Wewa & 34 & 159 & 47 & 21 & sand & black & 33 & 6.9 & 0.35 & 0 \\
\hline Thisa Wewa & 34 & 736 & 48 & 4 & sand & yellow & 31 & 6.7 & 0.12 & 0 \\
\hline $\begin{array}{l}\text { Mahakanadarawa } \\
\text { Wewa }\end{array}$ & 31 & 64 & 60 & 17 & sand & $\begin{array}{l}\text { very dark } \\
\text { grayish-brown }\end{array}$ & 28 & 7.0 & 9.14 & 0 \\
\hline $\begin{array}{l}\text { Nachchaduwa } \\
\text { Wewa }\end{array}$ & 32.8 & 256 & 53 & 10 & sand & $\begin{array}{c}\text { dark yellowish- } \\
\text { brown }\end{array}$ & 33 & 7.0 & 7.94 & 0 \\
\hline Kala Wewa & 38.5 & 618 & 52 & 6 & sand & light olive brown & 32 & 7.0 & 0.64 & 0 \\
\hline $\begin{array}{l}\text { Parakrama } \\
\text { Samudra }\end{array}$ & 29.5 & 64 & 63 & 3 & sand & $\begin{array}{l}\text { light yellowish- } \\
\text { brown }\end{array}$ & 30 & 7.5 & 0.15 & 0 \\
\hline Kandalama Wewa & 33 & 56 & 58 & 9 & sand & brownish-yellow & 33 & 8.0 & 5.2 & 0 \\
\hline Devahuwa Wewa & 37 & 363 & 40 & 4 & sand & reddish-yellow & 38.5 & 6.8 & 0.13 & 0 \\
\hline Tabbowa Wewa & 39 & 206 & 41 & 7 & sand & light olive brown & 39 & 7.0 & 3.65 & 0 \\
\hline Batalagoda Wewa & 35.2 & 655 & 47 & 9 & sand & yellowish-brown & 42.5 & 6.8 & 11.49 & 0 \\
\hline Ridiyagama Wewa & 33 & 105 & 66 & 8 & sand & $\begin{array}{l}\text { dark reddish- } \\
\text { brown }\end{array}$ & 30 & 7.0 & 7.93 & 0 \\
\hline Average $\pm S E$ & $\begin{array}{c}34.27 \pm \\
2.96\end{array}$ & $\begin{array}{c}298.36 \pm \\
34.11\end{array}$ & $\begin{array}{l}52.27 \pm \\
8.65\end{array}$ & $\begin{array}{c}8.09 \pm \\
1.17\end{array}$ & & & $33.64 \pm 2.11$ & $\begin{array}{l}7.08 \pm \\
0.63\end{array}$ & $\begin{array}{l}4.25 \pm \\
0.67\end{array}$ & \\
\hline
\end{tabular}

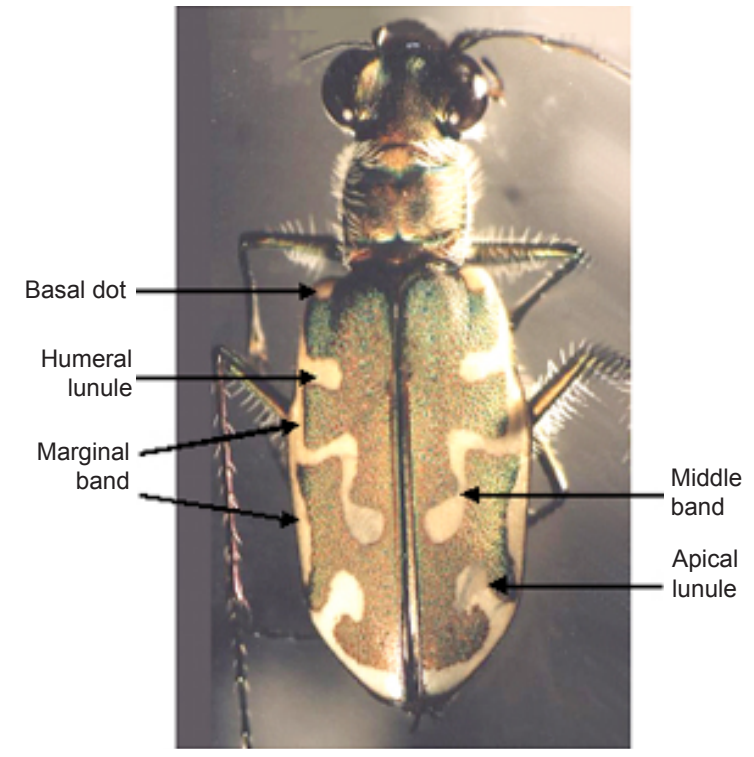

Image 2. Calomera angulata (x 10 x 1.0)

The species was found in nine out of 11 reservoirs and formed large populations of a single species in five of the habitats (Batalagoda Wewa, Kala Wewa, Mahakanadarawa Wewa, Parakrama Samudra, Thisa Wewa), while in the other four tank systems (Devahuwa Wewa, Kandalama Wewa, Nachchaduwa Wewa, Tabbowa Wewa) it co-occurred with either Myriochila (Monelica) fastidiosa, Cylindera (Oligoma) lacunosa or Lophyra (Lophyra) catena (Table 2). Even when co-occurring, Calomera angulata was more abundant

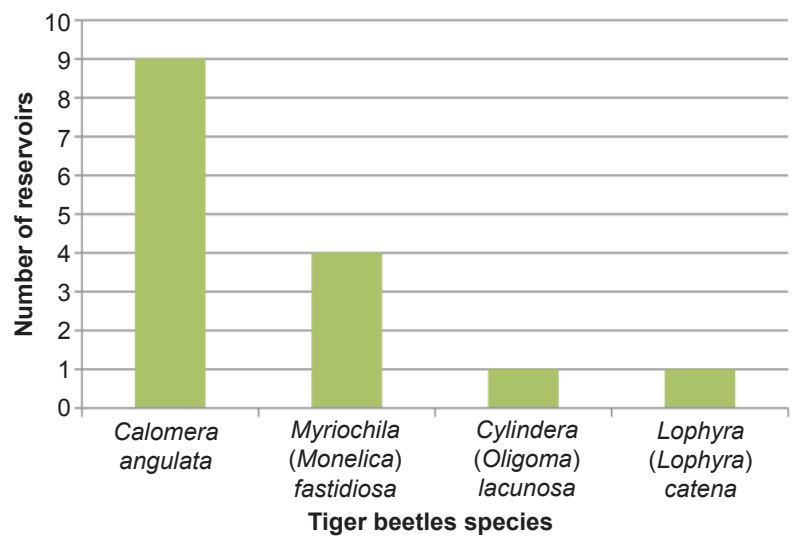

Figure 2. Distribution of Tiger Beetle species in reservoir ecosystems of Sri Lanka

than the other species.

\section{Myriochila (Monelica) fastidiosa (Dejean, 1825) (Image 3)}

Myriochila (Monelica) fastidiosa was recorded from four reservoir ecosystems of Sri Lanka. In three reservoirs, Kandalama Wewa, Nachchaduwa Wewa, Tabbowa Wewa, it co-occurred with Calomera angulata, while a single population was found at Nuwara Wewa, Anuradhapura (Table 2). 


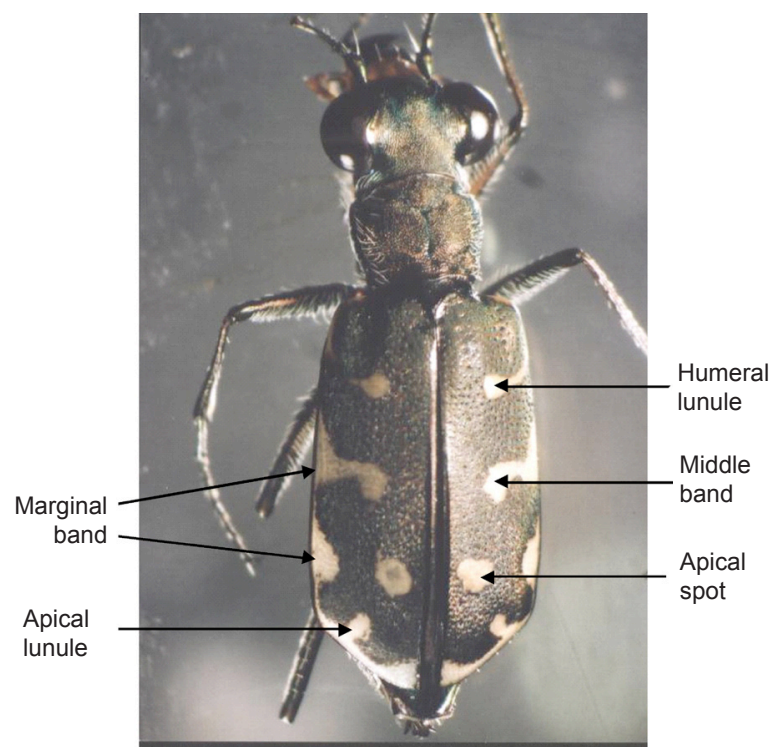

Image 3. Myriochila (Monelica) fastidiosa (x 10 x 1.0)

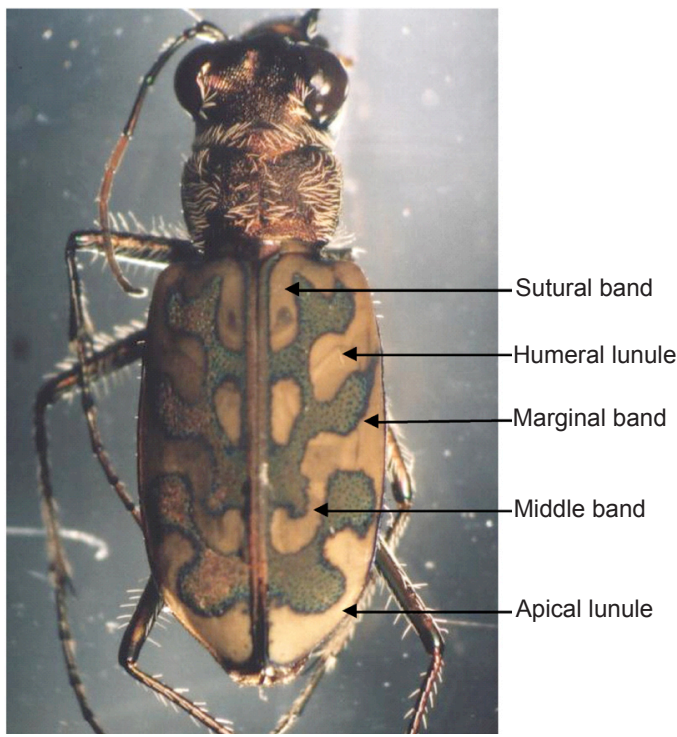

Image 5. Lophyra (Lophyra) catena (x $10 \times 1.0)$

\section{Cylindera (Oligoma) lacunosa (Putzeys, 1875)} (Image 4)

A single specimen of Cylindera (Oligoma) lacunosa was found co-occurring with Calomera angulata and Lophyra (Lophyra) catena at Devahuwa Wewa, Central Province. C. lacunosa occupied the wet sandy habitat most close to the water edge of the reservoir.

\section{Lophyra (Lophyra) catena (Fabricius, 1775) (Image 5)}

Lophyra (Lophyra) catena were encountered at

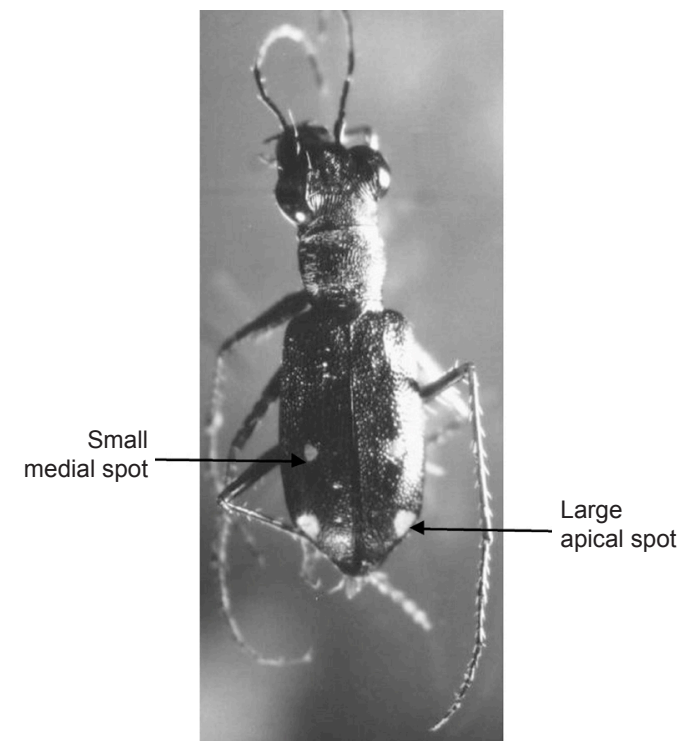

Image 4. Cylindera (Oligoma) lacunosa (x 10 x 1.5)

Devahuwa Wewa, Central Province and Ridiyagama Wewa, Southern Province (Table 2). The species occupied sandy bank area of the reservoir shaded by grasses and shrubs.

\section{DISCUSSION}

Reservoir ecosystems of Sri Lanka are riparian habitats that were constructed by humans about 2500 years ago (Bandaragoda 2006), and are integrated and inter-woven with the natural environment. The ecosystem consists of a reservoir, a sandy bank, a strip of trees downstream of the reservoir that act as a wind breaking barrier, and paddy fields. The sandy bank formed along the margin of the water level attracts many invertebrates due to accumulated organic matter and high food supply. Such riparian habitats are known to be preferred by tiger beetles not only because of adequate food resources but also due to safety from predators and low human disturbance (Bhargav \& Uniyal 2008).

Tiger beetles are known to be specialized species with narrow habitat requirements, hence changes in the habitat can lead to their disappearance (Diogo et al. 1999). Morphological differences between species of tiger beetles are apparently affected by selection for specific habitat requirements (Cardoso \& Vogler 2005). Therefore, the discovery of tiger beetles in the 
reservoir ecosystems of Sri Lanka, identification of the species and recordings of habitat conditions of the ecosystems is of utmost importance.

Tiger beetles are predatory insects that prefer riverine habitats with sandy soils and minimal vegetation, where periodic disturbance by wind and water removes encroaching vegetation (Warren \& Buttner 2008). Female tiger beetles are specific in choosing oviposition sites, as larval stages are soil dwelling and spend their entire life in the same location (Brust et al. 2006). The larvae of Cicindela hirticollis of Nebraska, USA are known to select burrow locations with at least $7 \%$ soil moisture to avoid difficulties associated with digging in loose, dry sand and to avoid abrasion of soft-bodied larvae. Further, soil moisture is known to be necessary for cohesion of soil particles and to prevent the collapse of the burrow walls (Brust et al. 2006). However, certain species that have evolved as sand dune species are known to prefer a soil moisture of less than $4 \%$ and have higher amounts of cuticular hydrocarbons to avoid dessication (Romey \& Knisley 2002). The tiger beetle species of the reservoir ecosystems of Sri Lanka were found on soils of $4.25 \pm 0.67 \%$ moisture, a value in between the above extremes. The colour of the soil on which they occur is also known to be correlated with the structural colouration of species, an apparent adaptation for remaining inconspicuous to natural enemies reliant on visual cues (Seago et al. 2009). The closely packed pits on the elytral surface of tiger beetles and the surface microsculpture of the elytron is capable of reflecting wavelengths that create a diffuse matte brown, green or similarly unsaturated hue; often matching the colour of the surrounding soil (Seago et al. 2009).

The soils of the reservoirs of Sri Lanka inhabited by cicindelids were mainly brown, matching the bronze, copper-green and copper-brown colours of Calomera angulata, Myriochila (Monelica) fastidiosa, Lophyra (Lophyra) catena and Cylindera (Oligoma) lacunosa. The expanded white maculations on the elytra may have functioned in lowering the body temperature making them able to forage longer without overheating. According to Seago et al. (2009), Cicindela formosa and Neocicindela perhispida found on white beaches have expanded white maculations that significantly lowers the body temperature and enabling them to forage longer without overheating. The environmental
Table 4. Morphometric characters recorded for the tiger beetle species of reservoir ecosystems of Sri Lanka

\begin{tabular}{|l|c|c|c|}
\hline Species & $\begin{array}{c}\text { Body } \\
\text { Weight } \\
(\mathbf{m g})\end{array}$ & $\begin{array}{c}\text { Body } \\
\text { Length } \\
(\mathbf{m m})\end{array}$ & $\begin{array}{c}\text { Left } \\
\text { Mandible } \\
\text { Length }(\mathbf{m m})\end{array}$ \\
\hline Calomera angulata & $\begin{array}{c}54.69 \pm 3.19 \\
(\mathrm{n}=25)\end{array}$ & $\begin{array}{c}11.31 \pm 0.88 \\
(\mathrm{n}=25)\end{array}$ & $\begin{array}{c}2.33 \pm 0.53 \\
(\mathrm{n}=17)\end{array}$ \\
\hline $\begin{array}{l}\text { Cicindela (Monelica) } \\
\text { fastidiosa }\end{array}$ & $\begin{array}{c}52.57 \pm 2.14 \\
(\mathrm{n}=9)\end{array}$ & $\begin{array}{c}11.72 \pm 0.74 \\
(\mathrm{n}=9)\end{array}$ & $\begin{array}{c}2.26 \pm 0.51 \\
(\mathrm{n}=2)\end{array}$ \\
\hline $\begin{array}{l}\text { Cicindela (Oligoma) } \\
\text { lacunosa }\end{array}$ & $17.9(\mathrm{n}=1)$ & $8.1(\mathrm{n}=1)$ & - \\
\hline $\begin{array}{l}\text { Cicindela (Lophyra) } \\
\text { catena }\end{array}$ & $74.7(\mathrm{n}=1)$ & $11.4(\mathrm{n}=1)$ & $2.35(\mathrm{n}=1)$ \\
\hline
\end{tabular}

temperature of the reservoir ecosystems which was $34.27 \pm 2.96^{\circ} \mathrm{C}$ may also be suitable for the occurrence of tiger beetles as ground temperature ranging from $32-33^{\circ} \mathrm{C}$ is known to be suitable for the activity and viability of tiger beetle populations, and a temperature of $34-35^{\circ} \mathrm{C}$ determined the greatest number of matings in Cicindela (Cephalota) circumdata leonschaeferi Cassola (Eusebi et al. 1989).

Calomera angulata was the most common tiger beetle species found in a majority of reservoir ecosystems. When co-occurring it was far more abundant than the other species and only single specimens of $L$. catena and $C$. lacunosa were found co-occurring with $C$. angulata at Devahuwa wewa. The low number of sympatric tiger beetle species in reservoir habitats may be due to competition for food resources as all species in these habitats had more or less similar mandible lengths (Table 4).

Calomera angulata, the key tiger beetle species of the reservoir ecosystems of Sri Lanka, has been reported from Sri Lanka as far back as 1904 (by Horn) and 1912 (by Fowler). However, it was identified as Cicindela sumatrensis Herbst 1806 and was reported from riverine and coastal locations, and certain other locations where the habitat is not defined. Wiesner (1975) and Acciavatti \& Pearson (1989) have recorded Calomera angulata from India and Nepal, but have not recorded the species from Sri Lanka. Wiesner (1975) reports that the species can be found near the water's edge on open, moist sandy banks of rivers. More recently, Shook (1987) has reported Calomera angulata from along river habitats in Thailand. However, Satoh \& Hori (2004) define Calomera angulata as a coastal tiger beetle occurring along the sea coast of Japan co-occurring with other tiger beetle species in most instances. 
Myriochila (Monelica) fastidiosa, a species restricted to Sri Lanka and India has been cited in several works of literature inhabiting grasslands, scrub forests, forest paths and old fields (Horn 1904; Fowler 1912; Naviaux 1984; Acciavatti \& Pearson 1989).

Lophyra (Lophyra) catena was first recorded in Sri Lanka in 1860 by Tennent, and later by Horn (1904), Fowler (1912), Naviaux (1984) and Acciavatti \& Pearson (1989). Naviaux (1984) reported the species from margins of rivers and lagoons by the ocean, as well as in large sunny forest clearings. However, field work done in the present study (December 2003 to November 2005) also revealed the species from sandy lawns, foot paths and dry sand of coastal areas away from the water.

Cylindera (Oligoma) lacunosa, a species restricted to Sri Lanka and Tamil Nadu, India, has been reported from forest openings of Sri Lanka (Horn 1904; Fowler 1912; Naviaux 1984; Acciavatti \& Pearson 1989).

None of the above tiger beetle species are endemic to Sri Lanka and can be found in the Indian subcontinent and countries of South East Asia. The vast majority of the endemic flora and fauna of Sri Lanka are restricted to the wet zone of the country as are the tiger beetle species (Dangalle et al. 2011a,b). Therefore, the reservoir habitats of Sri Lanka are perhaps less important than other habitats for supporting endemic tigerbeetle species. However, the reservoir habitats may have facilitated the dispersion of tiger beetles within Sri Lanka and may have played a role in facilitation of colonization of wet zone habitats by the endemic tiger beetles, by provision of transitional habitats. The two endemic tiger beetle species, Cylindera (Ifasina) waterhousei and Cylindera (Ifasina) willeyi, reported from the wet zone of Sri Lanka (Dangalle et al. 2011a,b) are species of the genus Cylindera which occurs in subtropical and temperate regions of Africa, Madagascar, Eurasia, Asia and South-East Asia (Sota et al. 2011). According to Pearson \& Ghorpade (1989) these taxa dispersed to Sri Lanka using continuous forest habitats that were available from south-eastern Asia to the Indian subcontinent, and traveled down the Western and Eastern Ghats to reach central Sri Lanka which was continuous with the southern division of the Western Ghats. The reservoir habitats may have provided a suitable habitat for the dispersal of these small bodied beetles with weak flying abilities. Similarly, as many tanks are connected to a network of canals and streams and thus indirectly to major rivers, it is tempting to theorize that coastal zone species would have made the transition to reservoir habitats along such interconnected waterways. More data on the occurrence and viability of tiger beetle populations along the canal and stream networks of the ancient tank system needs to be collected.

In conclusion our study reveals that reservoir (tank) habitats which are man-made and dating back thousands of years have been colonized ('invaded as new habitat') by tiger beetle species which are known to occupy other types of habitats elsewhere in the world. Suitable climatic and soil conditions of the locations have facilitated the occurrence of tiger beetle species in these habitats and the study reports the habitat preferences of the species of reservoir ecosystems of Sri Lanka.

\section{REFERENCES}

Acciavatti, R.E. \& D.L. Pearson (1989). The tiger beetle genus Cicindela (Coleoptera, Insecta) from the Indian subcontinent. Annals of Carnegie Museum 58(4): 77-355.

Adis, J., W. Paarmann, M.A. Amorim, E. Arndt \& C.R.V. da Fonseca (1998). On occurrence, habitat specificity and natural history of adult tiger beetles (Coleoptera:Carabidae: Cicindelinae) near Manaus, Central Amazonia, and key to the larvae of tiger beetle genera. Acta Amazonica 28(3): 247-272.

Bandaragoda, D.J. (2006). Limits to donor-driven water sector reforms: Insight and evidence from Pakistan and Sri Lanka. Water Policy 8: 51-67.

Bhargav, V.K. \& V.P. Uniyal (2008). Communal roosting of tiger beetles (Cicindelidae:Coleoptera) in the Shivalik Hills, Himachal Pradesh, India. Cicindela 40(1-2): 1-12.

Bierman, P. (2007). Management solutions to soil limitations. State Master Gardener Conference, Department of Soil, Water and Climate, University of Minnesota, 9pp.

Brust, M., W. Hoback, K.F. Skinner \& C.B. Knisley (2006). Movement of Cicindela hirticollis Say larvae in response to moisture and flooding. Journal of Insect Behavior 19(2): 251-263.

Cardoso, A. \& A.P. Vogler (2005). DNA taxonomy, phylogeny and Pleistocene diversification of the Cicindela hybrid species group (Coleoptera:Cicindelidae). Molecular Ecology 14: 3531-3546.

Dangalle, C., N. Pallewatta \& A.P. Vogler (2011a). The current occurrence, habitat and historical change in the distributional range of an endemic tiger beetle species Cicindela (Ifasina) willeyi Horn (Coleoptera: Cicindelidae) of Sri Lanka. Journal of Threatened Taxa 3(2): 1493- 
1505.

Dangalle, C., N. Pallewatta \& A.P. Vogler (2011b). The occurrence of the endemic tiger beetle Cicindela (Ifasina) waterhousei in Bopath Ella, Ratnapura, Sri Lanka. Journal of the National Science Foundation of Sri Lanka. 39(2): 163-168.

De Silva, S.S. (1988). Reservoirs in Sri Lanka and their fisheries. FAO Fisheries Technical Paper 298: 128.

Diogo, A.C., A.P. Vogler, A. Gimenez, D. Gallego \& J. Galian (1999). Conservation genetics of Cicindela deserticoloides, an endangered tiger beetle endemic to southeastern Spain. Journal of Insect Conservation 3: 117-123.

Eusebi, M.P., L. Favilli \& S. Lovari (1989). Some abiotic factors affecting the activity and habitat choice of the tiger beetle Cephalota circumdata leonschaeferi (Cassola) (Coleoptera, Cicindelidae). Italian Journal of Zoology 56(2): 143-150.

Fowler, W.W. (1912). Fauna of British India including Ceylon and Burma (Coleoptera general introduction and Cicindelidae and Paussidae). Reprinted by Today and Tomorrow's Printers and Publishers, (1973), New Delhi, $529 \mathrm{pp}$. Original is by Taylor and Francis

Horn, W. (1904). The Cicindelidae of Ceylon. Spolia Zeylanica 2(5): 30-45.

IUCN, The World Conservation Union (2006). Fauna of Sri Lanka: Status of Taxonomy, Research and Conservation. 308pp.

Knisley, C.B. \& J.M. Hill (1992). Effects of habitat change from ecological succession and human impact on tiger beetles. Virginia Journal of Science 43(1): 133-142.

Lorenz, W. (1998). Systematic list of extant ground beetles of the world (Insecta Coleoptera "Geoadephaga": Trachypachidae and Carabidae incl. Paussinae, Cicindelinae, Rhysodinae). Tutzing, Germany, 490pp.

Morgan, M., C.B. Knisley \& A.P. Vogler (2000). New taxonomic status of the endangered tiger beetle Cicindela limbata albissima (Coleoptera:Cicindelidae): Evidence from mtDNA. Ecology and Population Biology 93(5): $1108-1115$.

Naviaux, R. (1984). Coleoptera, Cicindelidae. Les Cicindelés de Sri Lanka. Revue Scientifique Du Bourbonnais 57-80.

Pearson, D.L. \& F. Cassola (2007). Are we doomed to repeat history? A model of the past using tiger beetles (Coleoptera: Cicindelidae) and conservation biology to anticipate the future. Journal of Insect Conservation 11: 47-59.

Pearson, D.L. \& K. Ghorpade (1989). Geographical distribution and ecological history of tiger beetles (Coleoptera:Cicindelidae) of the Indian subcontinent. Journal of Biogeography 16: 333-344.

Romey, W.L. \& C.B. Knisley (2002). Microhabitat segregation of two Utah sand dune tiger beetles (Coleoptera: Cicindelidae). The Southwestern Naturalist 47(2): 169 174.

Satoh, A. \& M. Hori (2004). Interpopulation differences in the mandible size of the coastal tiger beetle Lophyridia angulata associated with different sympatric species. Entomological
Science 7: 211-217.

Satoh, A., T. Ueda, E. Ichion \& M. Hori (2006). Distribution and habitat of three species of riparian tiger beetle in the Tedori River System of Japan. Community and Ecosystem Ecology 35(2): 320-325.

Seago, A.E., P. Brady, J. Vigneron \& T.D. Schultz (2009). Gold bugs and beyond: a review of iridescence and structural colour mechanisms in beetles (Coleoptera). Journal of the Royal Society Interface 6: S165-184.

Shook, G.A. (1987). A preliminary list of the tiger beetle genus Cicindela from Thailand. Cicindela 19(1): 13-20.

Sota, T., H. Liang, Y. Enokido \& M. Hori (2011). Phylogeny and divergence time of island tiger beetles of the genus Cylindera (Coleoptera:Cicindelidae) in East Asia. Biological Journal of the Linnean Society 102: 715-727.

Tennent, J.E. (1860). Ceylon: An account of the island physical, historical and topographical with notices of its natural history, antiquities and productions. Longman \& Roberts, London, 643pp.

Warren, S.D. \& Buttner, R. (2008). Active training military areas as refugia for disturbance dependent endangered insects. Journal of Insect Conservation 12(6): 671-676.

Wiesner, J. (1975). Notes on Cicindelidae of India and Sri Lanka. Cicindela 7(4): 61-70.

Wiesner, J. (1992). Checklist of the Tiger Beetles of the World: (Coleoptera, Cicindelidae). Verlag Erna Bauer, Keltern, Germany, 364pp.

Author Details: Dr. Chandima Dangalle is a Senior Lecturer in Zoology, attached to the University of Colombo, Sri Lanka. Her expertise lies in the fields of Entomology and Molecular Biology. Her research focuses on collecting baseline data on the distribution and habitat preferences of tiger beetles in Sri Lanka. Further, she studies the evolution and phylogeny of the species using mitochondrial DNA sequences of collected specimens. She conducted her PhD in the Department of Zoology, University of Colombo, Sri Lanka and Department of Entomology, Natural History Museum, London, United Kingdom.

Dr. Nirmalie Pallewatta is a Senior Lecturer and the current head of the department of Zoology, University of Colombo, Sri Lanka. A zoologist by training, she received her $\mathrm{PhD}$ in 1986 from the Imperial College of Science, Technology and Medicine at the University of London, United Kingdom.

Dr. Alfried Vogler works on the molecular systematics of Coleoptera. He has a joint position at the Natural History Museum and at Imperial College, London. Together with PhD students and postdocs, he is currently studying basal relationships of Scarabaeinae and Aphodiinae. He is also interested in the factors determining the composition of dung beetle communities and the effect of species interactions on the evolution of ecomorphological diversity. 